\title{
Power system stress analysis for main grid substations in Brazil
}

\author{
Análisis del esfuerzo en sistemas eléctricos de potencia para \\ subestaciones de redes principales en Brasil
}

\author{
Paulo R. Duailibe Monteiro ${ }^{1 *} \quad$ Leonardo de C. Rocha ${ }^{2}$ \\ Carlos A. P. Soares ${ }^{1} \quad$ Wainer S. Silva ${ }^{1}$ \\ Recibido 5 de marzo de 2015, aceptado 4 de septiembre de 2015 \\ Received: March 5, 2015 Accepted: September 4, 2015
}

\begin{abstract}
The analyses for overcoming problems arising in basic grid substation buses and equipment are of essential importance to the Brazilian electric sector in view of the constant expansion of this system. These analyses are not simple tasks because they involve an evaluation of the impacts caused by installations arising from new connections and because they always include various studies. This paper presents examples of necessary investigations into the causes of the rated characteristic violations of basic grid installation components. An overview of the proposed electrical system that will be evaluated in conjunction with a new thermal generator plant connection to an existing system substation system is presented.
\end{abstract}

Keywords: Overrating, substation, load flow, short circuit, transient recovery voltage, insulation coordination.

\section{RESUMEN}

El análisis de superación de equipos y barras en subestaciones existentes pertenecientes a la red básica es de fundamental importancia para el sector de la energía, con vistas a la constante expansión del sistema. Este análisis no es una tarea sencilla, ya que la evaluación de los impactos causados en esas instalaciones, como resultado de una nueva conexión, implica diferentes estudios. En este artículo se presenta por medio de un ejemplo de caso, los estudios necesarios sobre el análisis de violación de las características nominales de los principales componentes de la instalación de la red básica. Se propone para que sea evaluado un sistema eléctrico con la conexión de una nueva central termoeléctrica en una subestación existente.

Palabras clave: Superación de equipos, subestación, flujo de energía, cortocircuito, tensión de restablecimiento transitoria, coordinación de aislamiento.

\section{INTRODUCTION}

The Brazilian national integrated system (NIS) is undergoing constant expansion resulting from the entry of new and varied energy-source electric energy generator plants stimulated by growing consumer demands.

The new generation plants contribute much-needed energy to the NIS by connecting with existing

\footnotetext{
1 Programa de Pós-Graduação em Engenharia Civil. Universidade Federal Fluminense - UFF. Rua Passo da Pátria, 156, Bloco D, Sala 365, Niterói, CEP 24210-240. Rio de Janeiro, Brasil. E-mail: pauloduailibe@id.uff.br; carlos.uff@globo.com; wainer_uff@yahoo.com.br

2 Petróleo Brasileiro S/A - PETROBRAS, Rua Henrique Valadares, 28, $1^{\circ}$ andar, bloco A. CEP 20231-030. Rio de Janeiro, Brasil. E-mail: leonardo_carvalho@petrobras.com.br

* Corresponding author
} 
installations in the basic grid either through the sectioning of transmission lines (TL) or connections to substations (SE). This study focuses on existing substation connections.

Substation electrical equipment must be adequately specified to remain in service for a period of time that is sufficient to compensate for their purchase and installation costs. Accordingly, basic grid substations must be capable of absorbing expansions in the electrical system through a new connection; as such, equipment must be sized because of the purchasing time required to absorb the increases in demand during their lifetime [1].

A good reference for defining equipment and substation installation specifications is shown in the respective regional energy expansion plans in Brazil from information obtained from the Empresa de Pesquisa Energética - EPE [2].

However, additional changes or expansions not originally foreseen in the original operational project may be necessary.

In this respect, periodic government energy auctions provide opportunities and incentives for the insertion of new electric energy generation plants, mainly thermal and wind farms projects that are usually simpler and faster to construct when compared to major hydroelectric projects. Frequently, the construction of some thermal plants is not foreseen in the expansion plan.

In the case of a new thermal generation plant connection, an impact study on the connections at the designated substation will be necessary to identify whether the electrical limits of substation bus bars and equipment will be exceeded; there are many studies to diagnose the problem. According to [1], a comparison must be made for load currents, short circuit currents and transient recovery voltage - TRV of the system by considering the new scenario in view of the existing substation buses and equipment characteristics.

The determination of load currents at every section of the substation can be obtained through load flow studies. The calculation method adopted may be seen in [3]. Equally, it is necessary to verify the current values for each bay arising from single phase and three-phase short circuits applied to buses at the connecting substation and at adjacent substations in the system. The theoretical approach for this calculation may be examined in [4].

The mathematical tools and premises for the resolution of transient phenomena have been posted in [5]. Procedures and calculations for TRV evaluation in a high voltage circuit breaker are in [6-8]. In [9], the differences between IEC and ANSI standards are examined to aid in the TRV evaluation.

The overcoming analysis of existing buses and equipment related to new generation connections may indicate the need for additional investments to safely and successfully connect the plant to the substation. In some cases, these additional investments may exclude a connection alternative or even make a connection project unfeasible due to the high cost of re-capacitating buses and substitute equipment.

The objective of this paper is to present the main studies needed to determine overrating problems in buses and equipment for new plant link-ups to existing $230 \mathrm{kV}$ substations. This new connection may considerably increase the level of short circuits and power flow and change the substation topology due to new connection bays.

\section{TEST SYSTEM}

A fictitious $550 \mathrm{MW}$ capacity generation plant was created and was designed to inject power into the NIS through an existing $230 \mathrm{kV}$ substation link (also fictitious), with pre-defined bus and equipment specifications to facilitate the analysis. The transmission of electric power generated by the simulated thermal plant to the substation, currently denominated as SE-01, is performed through a double circuit, transmission line of approximately $10.7 \mathrm{~km}$ long.

The SE-01 substation is a four-switch, double bus bar configuration, with its existing in-line five-bay topology (EL), and an expansion project consisting of two additional in-line bays that receive power from the new thermal plant. Figure 1 presents a simplified view of the SE-01 topology.

SE-01 rated bus and equipment characteristics are mentioned throughout this paper. Figure 1 


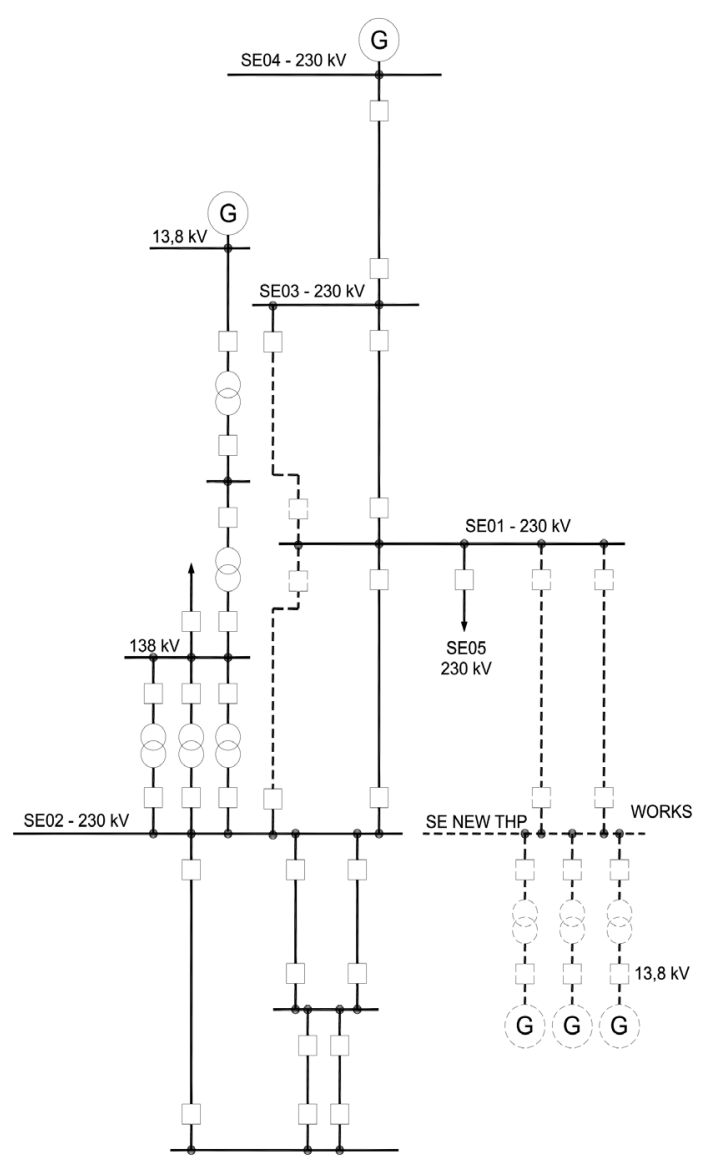

Figure 1. Fictitious Test System.

shows the proposed electric system adopted for the SE-01 region of influence under examination. Furthermore, in this figure, expansion work needed for the connection at SE-01 is included.

\section{LOAD FLOW ANALYSIS}

The first analysis recommended to verify the presence of problems is load flow supportability within the electrical limits of SE-01 buses and equipment during normal operation by considering some possible contingencies, or, in other words, an evaluation of load current supportability.

This method consists of comparing rated bus and equipment currents with currents supplied by load flow studies during normal operations by considering future configurations and systemic contingencies, maintenance mode and operations, including circuit breaker maintenance.
To determine the internal current distribution in each bus section $(230 \mathrm{kV})$ belonging to SE-01, simulations were conducted using ATPDraw software [10] by considering the worst power flow scenario (see Figure 2). The methodology of the analysis was based on power flow injections in the respective bays and the verification of their distribution through buses and equipment. The verified values were compared to the rated capacities of various elements. Systemic contingencies were considered, including the shutdown of one of the substation connecting transmission lines (n-1) and other operational contingencies based on substation topology variations.

For simulation purposes, SE-01 was modeled with double buses and 4-switches and two transmission lines - TL connections originating at the new thermal plant- new ThP by considering the physical layout of the line entry bays and the bus interconnection bay, as seen in Figure 3.

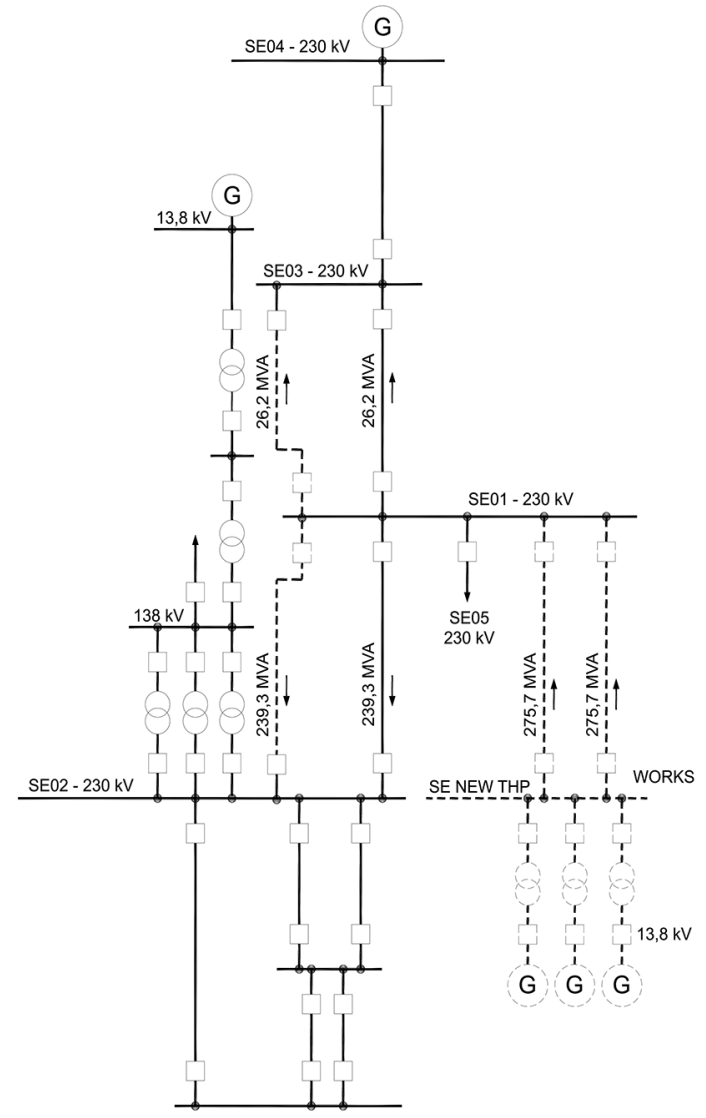

Figure 2. Power Flow Base Case. 


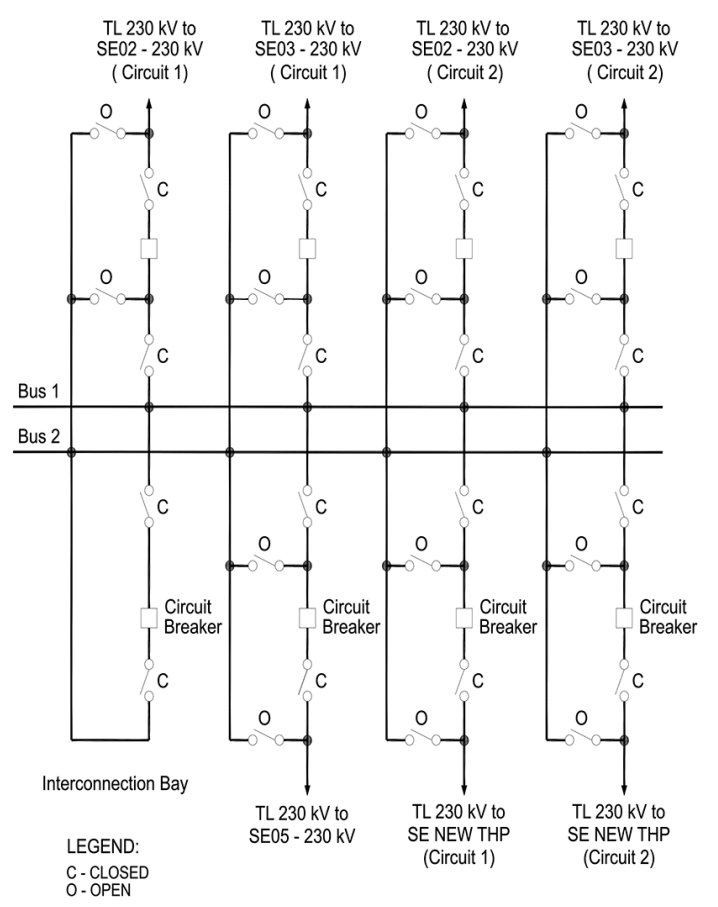

Figure 3. SE-01 configuration after connection to the new ThP.

For the scenario presented in Figure 2, Table 1 presents the systemic contingencies (n-1) that were analyzed and the power flow through the buses and equipment at SE-01 for each contingency considered:

The two operational contingencies at SE-01 that follow were deemed the most critical. Analyses were made for the worst-case power flow scenarios and all contingencies as shown in Table 1.

- Case 1: Bus B2 out of operation; all entry bays connected through Bus B1, as shown in Figure 4;

- Case 2: Total thermal plant generation injected through Bus B2 via TL's SE-01 - SE new ThP

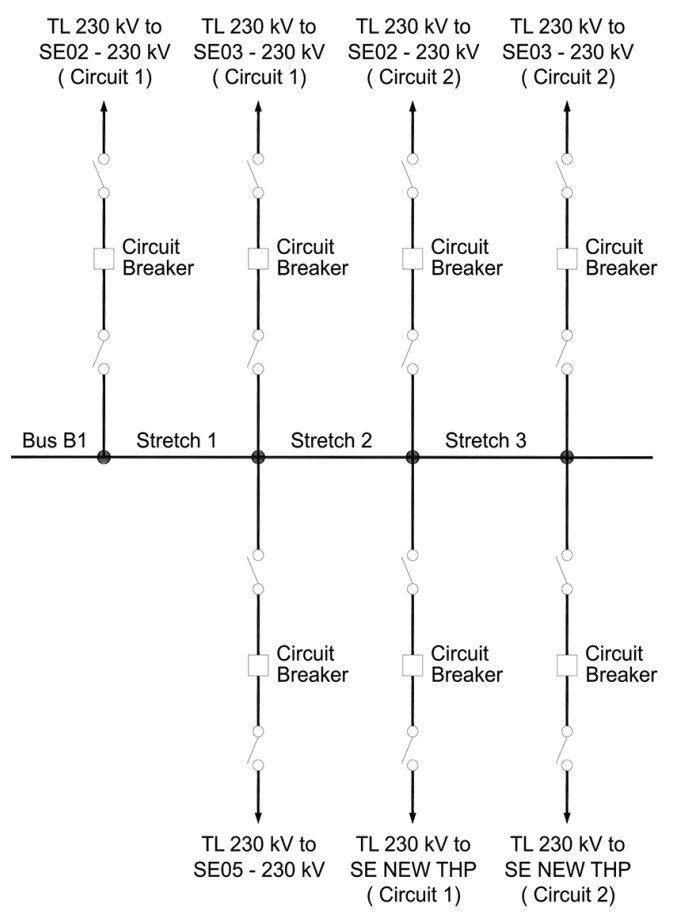

Figure 4. Case 1: Bus B2 - out of operation; all connections through B1 bays.

entry line bays and all entry bays connected through Bus B1, as shown in Figure 5.

The current distribution at SE-01 is shown in Table 2 for Case 1.

The current distribution at SE-01 is shown in Table 3 for Case 2.

Based on the current values obtained, the existing buses and equipment were evaluated at SE-01 to check whether any rated current has been violated. Bus and equipment current ratings and maximum current in these same devices -after the new

Table 1. Systemic contingencies (n-1).

\begin{tabular}{|c|c|c|c|c|c|c|c|c|}
\hline \multirow{2}{*}{ Number } & Contingencies & $\begin{array}{c}\text { TL SE 01 - } \\
\text { SE 02 } \\
\text { C1 (MVA) }\end{array}$ & $\begin{array}{c}\text { TL SE 01 - } \\
\text { SE 03 } \\
\text { C1 (MVA) }\end{array}$ & $\begin{array}{c}\text { TL SE 01 - } \\
\text { SE 02 C2 } \\
\text { (MVA) }\end{array}$ & $\begin{array}{c}\text { TL SE 01- } \\
\text { SE 03 } \\
\text { C2 (MVA) }\end{array}$ & $\begin{array}{c}\text { TL SE 01 - } \\
\text { SE 05 } \\
\text { (MVA) }\end{array}$ & $\begin{array}{c}\text { TL SE 01- } \\
\text { SE NEW } \\
\text { THP C1 } \\
\text { (MVA) }\end{array}$ & $\begin{array}{c}\text { TL SE 01- } \\
\text { SE NEW } \\
\text { THP C2 } \\
\text { (MVA) }\end{array}$ \\
\hline 1 & TL SE 01-SE 02 C1 & 0.00 & 33.60 & 460.4 & 33.60 & 25.20 & 275.70 & 275.70 \\
\hline 2 & TL SE 01- SE 03 C1 & 242.80 & 0.00 & 241.80 & 47.70 & 25.20 & 276.40 & 276.40 \\
\hline 3 & TL SE 01-SE 02 C2 & 460.40 & 33.60 & 0.00 & 33.60 & 25.20 & 275.70 & 275.70 \\
\hline 4 & TL SE 01- SE 03 C2 & 241.80 & 47.70 & 241.80 & 0.00 & 25.20 & 276.40 & 276.40 \\
\hline 5 & TL SE 01- SE 05 & 249.30 & 28.70 & 249.30 & 28.70 & 0.00 & 276.30 & 276.30 \\
\hline
\end{tabular}




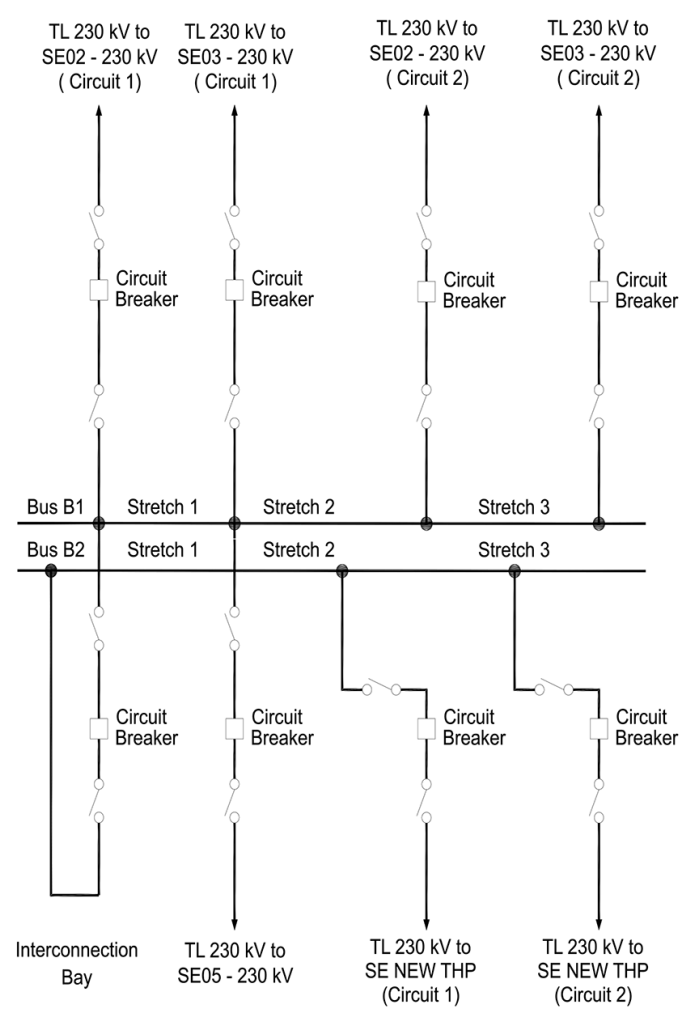

Figure 5. Case 2: new thermal plant connected to Bus B2, remaining bays connected to Bus B1.

connection was made- were ascertained through simulations and are presented in Table 4.

The shaded values show that rated current limits were exceeded in the equipment and /or buses, indicating the need for the substitution of components to assure safe operation of new, expanded power flow conditions.

Based on the results obtained through simulations, with the entry of new lines at SE-01, the forecasted maximum current at buses B1 and B2 shall be equal to 1397 A that was obtained in Case 2, as studied. The rated current capacity in these buses is $775 \mathrm{~A}$, as shown in Table 4. In spite of the fact that bus sections presented different maximum currents, including values below $775 \mathrm{~A}$, it is a good engineering practice to assume that all buses present the same rated sections, which makes the need for re-capacitating the whole bus bar evident. Clearly, this measure is recommended in a scenario where investment resources are available and where implanting restrictive operational measures has been discarded. In case immediate investments are not possible or are even rejected, solutions must be studied to overcome the problems identified to make the postponing of equipment substitutions or the reinforcing of buses in question feasible. In [1], some suggestions are made to remediate this case.

For interconnection bay equipment, as shown in Table 4, the rated current capacities have been exceeded in all bay equipment due to the presence of maximum current -1397 A- as obtained in Case 2.

Regarding buses and equipment in the entry bay (TL SE-01 - SE-02 $230 \mathrm{kV} \mathrm{C1}$ ), a current value of 1156 A was obtained in Cases 1 and 2, in the event of a contingency in the second circuit belonging to TL SE-01-SE-02 (contingency 3). As shown in Table 4,

Table 2. SE-01 Currents - Case 1.

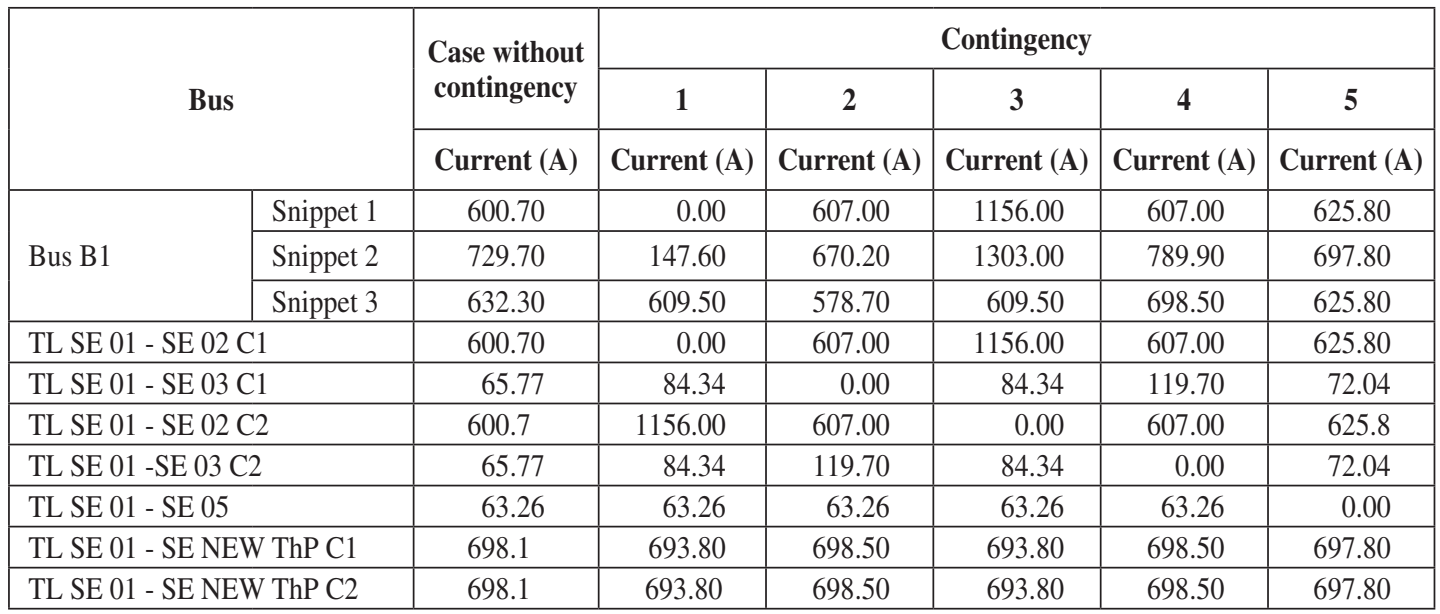


Table 3. SE-01 Currents - Case 2.

\begin{tabular}{|c|c|c|c|c|c|c|c|}
\hline \multirow{2}{*}{\multicolumn{2}{|c|}{ Bus }} & \multirow{3}{*}{$\begin{array}{l}\text { Case without } \\
\text { contingency }\end{array}$} & \multicolumn{5}{|c|}{ Contingency } \\
\hline & & & \multirow{2}{*}{$\frac{1}{\text { Current (A) }}$} & \multirow{2}{*}{$\frac{2}{\text { Current (A) }}$} & \multirow{2}{*}{$\frac{3}{\text { Current (A) }}$} & \multirow{2}{*}{$\frac{4}{\text { Current (A) }}$} & \multirow{2}{*}{$\frac{5}{\text { Current (A) }}$} \\
\hline \multirow{4}{*}{ Bus B1 } & & & & & & & \\
\hline & Snippet 1 & 795.68 & 1388.00 & 790.00 & 231.90 & 790.00 & 769.90 \\
\hline & Snippet 2 & 666.80 & 1240.00 & 726.7 & 84.34 & 607.00 & 697.80 \\
\hline & Snippet 3 & 65.77 & 84.34 & 119.70 & 84.34 & 0.00 & 72.04 \\
\hline \multirow{3}{*}{ Bus B2 } & Snippet 1 & 1397.00 & 1388.00 & 1397.00 & 1388.00 & 1397.00 & 1396.00 \\
\hline & Snippet 2 & 1397.00 & 1388.00 & 1397.00 & 1388.00 & 1397.00 & 1396.00 \\
\hline & Snippet 3 & 698.40 & 693.80 & 698.50 & 693.80 & 698.50 & 697.80 \\
\hline \multicolumn{2}{|c|}{ Interconnection bay } & 1397.00 & 1388.00 & 1397.00 & 1388.00 & 1397.00 & 1396.00 \\
\hline \multicolumn{2}{|c|}{ TL SE 01 - SE 02 C1 } & 601.00 & 0.00 & 607.00 & 1156.00 & 607.00 & 625.80 \\
\hline \multicolumn{2}{|c|}{ TL SE 01 - SE 03 C1 } & 65.77 & 84.34 & 0.00 & 84.34 & 119.00 & 72.04 \\
\hline \multicolumn{2}{|c|}{ TL SE 01 - SE 02 C2 } & 601.00 & 1156.00 & 607.00 & 0.00 & 607.00 & 625.80 \\
\hline \multicolumn{2}{|c|}{ TL SE 01 -SE 03 C 2} & 65.77 & 84.34 & 119.70 & 84.34 & 0.00 & 72.04 \\
\hline \multicolumn{2}{|c|}{ TL SE 01 - SE 05} & 63.26 & 63.26 & 63.26 & 63.26 & 63.26 & 0.00 \\
\hline \multicolumn{2}{|c|}{ TL SE 01 - SE NEW ThP C1 } & 698.40 & 693.80 & 698.50 & 693.80 & 698.50 & 697.80 \\
\hline \multicolumn{2}{|c|}{ TL SE 01 - SE NEW ThP C2 } & 698.40 & 693.80 & 698.50 & 693.80 & 698.50 & 697.80 \\
\hline
\end{tabular}

Table 4. The rated current violation analysis of the existing equipment - SE-01.

\begin{tabular}{|l|l|c|c|}
\hline \multirow{4}{*}{ Description } & \multicolumn{1}{|c|}{ Equipment } & $\begin{array}{c}\text { Rated } \\
\text { Current (A) }\end{array}$ & $\begin{array}{c}\text { Maximum Current } \\
\text { after new } \\
\text { connection (A) }\end{array}$ \\
\hline \multirow{5}{*}{ Entry Bay TL SE 01 - SE 02 230 kV C1 } & Line Trap & 1200 & 1156 \\
\cline { 2 - 4 } & Disconnect Switches & 1250 & 1156 \\
\cline { 2 - 4 } & Circuit Breaker & 1250 & 1156 \\
\cline { 2 - 4 } & Current Transformers & $600 \times 1200$ & 1156 \\
\cline { 2 - 4 } & Buses & $775^{1}$ & 1156 \\
\hline \multirow{5}{*}{ Entry Bay TL SE 01 - SE 03 230 kV C1 } & Line Trap & 1200 & 119.7 \\
\cline { 2 - 4 } & Disconnect Switches & 1250 & 119.7 \\
\cline { 2 - 4 } & Circuit Breaker & 1250 & 119.7 \\
\cline { 2 - 4 } & Current Transformers & $600 \times 1200$ & 119.7 \\
\cline { 2 - 4 } & Buses & $775^{1}$ & 119.7 \\
\hline \multirow{5}{*}{ Entry Bay TL SE 01 - SE 05 230 kV } & Line Trap & 1200 & 63.26 \\
\cline { 2 - 4 } & Disconnect Switches & 1250 & 63.26 \\
\cline { 2 - 4 } & Circuit Breaker & 1250 & 63.26 \\
\cline { 2 - 4 } & Current Transformer (Protection) & $300 \times 600$ & 63.26 \\
\cline { 2 - 4 } & Current Transformer (Measurement) & $100 \times 200$ & 63.26 \\
\cline { 2 - 4 } & Buses & $775^{1}$ & 63.26 \\
\hline \multirow{5}{*}{ Busbar interconnection bay } & Circuit Breaker & 1250 & 1397 \\
\cline { 2 - 4 } & Current Transformer & $600 \times 1200$ & 1397 \\
\cline { 2 - 4 } & Disconnect Switches & 1250 & 1397 \\
\cline { 2 - 4 } & Buses & $775^{1}$ & 1397 \\
\hline General Substation Module & Main Buses & 1397 \\
\hline
\end{tabular}

1 Ampacity obtained from Alubar catalogue - room temperature at $25^{\circ} \mathrm{C}$, conductor temperature at $75^{\circ} \mathrm{C}$, sun and wind speed equal to $1 \mathrm{~m} / \mathrm{s}$. 
the buses in this entry bay presented a rated current violation in the emergency operational mode. The current transformers in that bay are parallel-series types, so that their connections may be modified to operate with a rated current of $1200 \mathrm{~A}$.

No other electrical limit violations were observed in buses or equipment belonging to other bays.

\section{SHORT-CIRCUIT STUDY}

This topic presents the results of the analysis conducted to evaluate short-circuit currents and X/R values at SE-01 and to verify the new ThP connection impact on the substation. To make the study case more realistic, the database used was taken from the ONS (Operador Nacional do Sistema) [11] website for the northeast region of Brazil. The results shown consider a scenario typical of December 2015. The program used for the analyses was SAPREANAFAS 2.2, which was developed by CEPEL [12] [13]. The study also considered a new thermal plant consisting of generation units totaling $550 \mathrm{MW}$ of injection into the system. The following analyses were conducted:

- Evaluation of short-circuit levels before entry of the ThP (Case Base);

- Evaluation of short-circuit levels after entry of the ThP;

Regarding the supportability limits and symmetric short-circuit interruption capacity of equipment, the following premises were considered:

- Supportability: equipment short-circuits at SE - $230 \mathrm{kV}$ new ThP limited to $40 \mathrm{kA}$;

- Supportability: equipment short-circuits at SE-01 - $230 \mathrm{kV}$ limited to $20 \mathrm{kA}$.

The methodology consists of evaluating short-circuit current levels that could circulate in buses and various bays in the SE-01 plant and their respective $\mathrm{X} / \mathrm{R}$ values. Single and three-phase short circuits in SE-01 buses and adjacent substations were applied to verify the current flow in each bay of the Base Case and again, with the new ThP connection, to evaluate the impact resulting from the modification on the level of short circuits in the system.

Given that the focus of this study is based on evaluating the supportability of existing equipment, it is important to remember that bus bar interconnection circuit breaker switches must be able to substitute any of the other breakers in the SE- 01 configuration, existing or not, by requiring analyses of their respective contributions to the bays.

The X/R analysis is established through a simplified methodology presented in ONS Grid Procedures [14], which makes it possible to define the buses where connected circuit breakers are subject to a violation of its interruption capacity due to constant grid time and, therefore, must be analyzed in more detail by their owners.

The flowchart in Figure 6 shows the methodology adopted to analyze the violation of an asymmetric short-circuit current in circuit breakers by considering constant grid time in milliseconds $(\tau)$.

According to the criteria adopted, circuit breakers operating in low grid time but with short-circuit currents (Isc) calculated at greater than $90 \%$ of its rated short-circuit current (Irsc) shall be subjected to a detailed analysis by a transmission agent who can then establish whether there is a need to substitute the circuit breakers with models offering greater rated breaking current.

The results obtained appear in Tables 5 to 10 . The highest level of short-circuit currents in the substation were observed in SE-01 buses that were equal to $6.65 \mathrm{kA}$ for three-phase short circuits and $7.43 \mathrm{kA}$ for single-phase currents.

In a comparison with the Base Case, the new ThP NIS connection does not cause limit violations related to short circuit interruption capacities described in the premises used in this study.

Looking at $\mathrm{X} / \mathrm{R}$ values, this value corresponding to the current that flows through the TL SE-01 - SE new ThP coming from the new plant and caused by a short circuit in the three-phase SE-01 bus, presented a value of 21.2 corresponding to a constant time equal to $56.2 \mathrm{~ms}$. Because the circuit breaker on this line would have to interrupt a symmetrical current value of $2.85 \mathrm{kA}$, which corresponds to $7.13 \%$ of the interruption capacity of $40 \mathrm{kA}$, this breaker would indeed be capable of interrupting current in view of the values presented in Figure 6. 


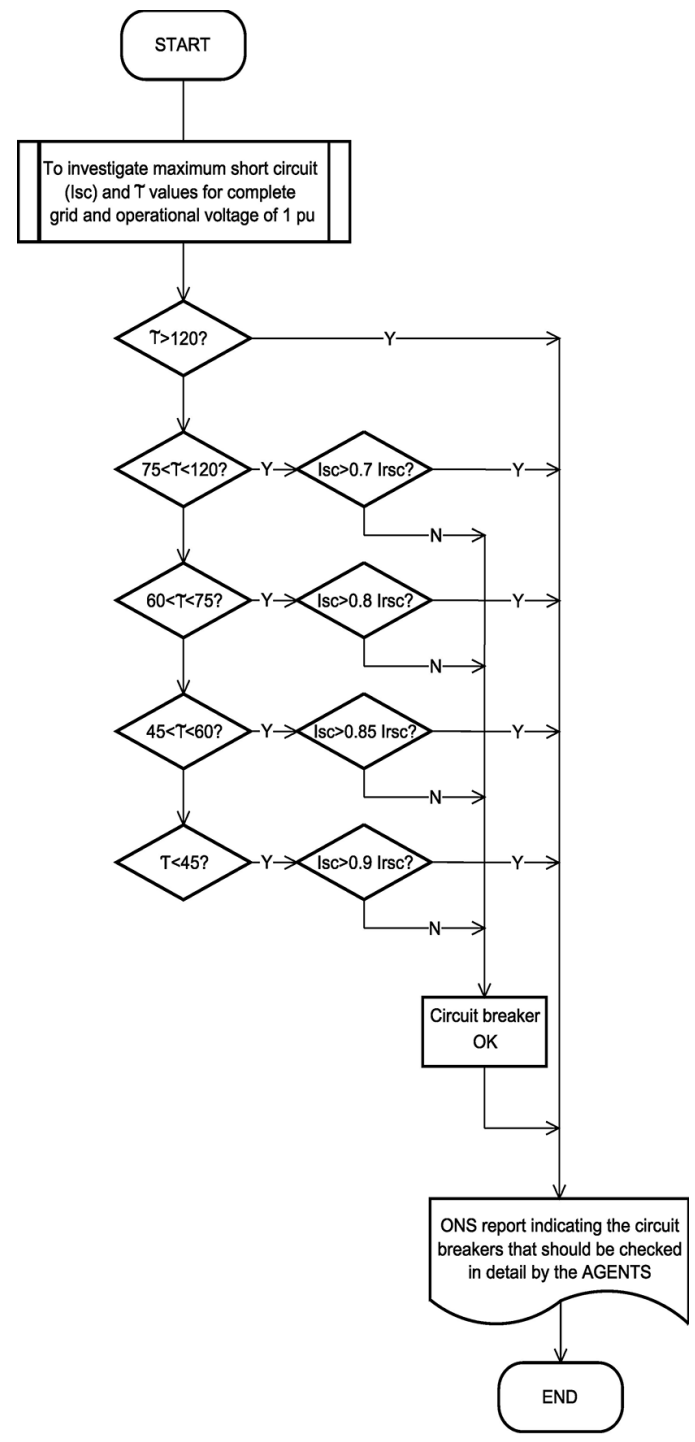

Figure 6. Verification of limit excesses in circuit breaker by Constant Time (in milliseconds) [14].
A second observation is that the $\mathrm{X} / \mathrm{R}$ value related to the current that flows through TL SE-01 - SE-05, caused by a single-phase short circuit application to the SE-01 bus, presented a value equal to $\mathrm{X} / \mathrm{R}$ 21.2 , corresponding to a constant time of $56.2 \mathrm{~ms}$. The circuit breaker on this line would have to interrupt the symmetrical current value of $0.34 \mathrm{kA}$, which corresponds to a symmetrical current equal to $1.7 \%$ of the rated breaking current of $20 \mathrm{kA}$. Therefore, this device would indeed be capable of interrupting current in view of the values presented in Figure 6.

In other cases, $\mathrm{X} / \mathrm{R}$ values were less than 17 (corresponding to a constant time equal to $45 \mathrm{~ms}$ ). All of the obtained symmetrical short circuit current values were less than $90 \%$ of the respective rated breaking current limits. Therefore, no violations of the limits proposed were foreseen.

\section{TRANSIENT RECOVERY VOLTAGE (TRV) STUDY}

This study presents the results of the TRV simulations applied to existing circuit breakers at SE-01 to verify impacts arising from a new thermal plant connection. The circuit breaker specifications are a $245 \mathrm{kV}$ rated voltage, a rated breaking current of $20 \mathrm{kA}$ and a first pole factor equal to 1.5 .

The TRVs evaluated are associated with circuit breaker interruption actions in the following faults:

- three-phase terminal faults (ungrounded and grounded) and single-phase in transmission line (short-line faults);

- three-phase faults (ungrounded and grounded) in $230 \mathrm{kV}$ buses at SE-01.

Table 5. Results: Bus Short-Circuit Study at SE-01 and adjacent substations.

\begin{tabular}{|l|c|c|c|c|c|c|c|r|}
\hline \multirow{2}{*}{ Bus } & \multicolumn{4}{|c|}{ Base Case } & \multicolumn{3}{c|}{ After ThP link-up } \\
\cline { 2 - 10 } & \multicolumn{2}{|c|}{ 3-phase } & Single Phase & \multicolumn{2}{c|}{ 3-phase } & \multicolumn{2}{c|}{ Single Phase } \\
\cline { 2 - 10 } & $\begin{array}{c}\text { Current } \\
(\mathbf{k A})\end{array}$ & $\mathbf{X} / \mathbf{R}$ & $\begin{array}{c}\text { Current } \\
(\mathbf{k A})\end{array}$ & $\mathbf{X / R}$ & $\begin{array}{c}\text { Current } \\
(\mathbf{k A})\end{array}$ & $\mathbf{X} / \mathbf{R}$ & $\begin{array}{c}\text { Current } \\
(\mathbf{k A})\end{array}$ & $\mathbf{X} / \mathbf{R}$ \\
\hline SE New ThP 230 kV & - & - & - & - & 11.29 & 13.00 & 12.68 & 12.99 \\
\hline SE 01 230 kV & 4.35 & 6.17 & 3.83 & 5.98 & 11.00 & 10.20 & 11.26 & 15.89 \\
\hline SE 02 230 kV & 6.84 & 7.11 & 7.12 & 8.03 & 10.82 & 8.26 & 10.58 & 7.92 \\
\hline SE 03 230 kV & 3.57 & 6.04 & 1.94 & 4.59 & 4.94 & 6.46 & 3.45 & 4.63 \\
\hline SE 05 230 kV & 3.89 & 5.97 & 3.49 & 6.24 & 8.50 & 8.14 & 7.79 & 6.94 \\
\hline
\end{tabular}


Table 6. SE-01 circuit breaker currents for short circuit applied to SE-01 buses.

(TL: Transmission Line).

\begin{tabular}{|c|c|c|c|c|c|c|c|c|}
\hline \multirow{3}{*}{ Circuit Breaker } & \multicolumn{4}{|c|}{ Base Case } & \multicolumn{4}{|c|}{ After ThP link-up } \\
\hline & \multicolumn{2}{|c|}{ 3-phase } & \multicolumn{2}{|c|}{ Single Phase } & \multicolumn{2}{|c|}{ 3-phase } & \multicolumn{2}{|c|}{ Single Phase } \\
\hline & $\begin{array}{c}\text { Current } \\
\text { (kA) }\end{array}$ & $\mathrm{X} / \mathrm{R}$ & $\begin{array}{c}\text { Current } \\
(\mathbf{k A})\end{array}$ & $\mathbf{X} / \mathbf{R}$ & $\begin{array}{c}\text { Current } \\
(\mathbf{k A})\end{array}$ & $\mathbf{X} / \mathbf{R}$ & $\begin{array}{c}\text { Current } \\
\text { (kA) }\end{array}$ & $\mathbf{X} / \mathbf{R}$ \\
\hline TL SE 01-SE $05230 \mathrm{kV}$ & 0 & 0 & 0.44 & 14.67 & 0 & 0 & 0.34 & 21.2 \\
\hline TL SE 01-SE 02230 kV C1 & 3.43 & 6.11 & 2.89 & 5.29 & 2.25 & 6.46 & 2.01 & 5.79 \\
\hline TL SE 01-SE 02230 kV C2 & - & - & - & - & 2.25 & 6.46 & 2.01 & 5.79 \\
\hline TL SE 01- SE 03230 kV C1 & 0.92 & 6.24 & 0.5 & 5.98 & 0.41 & 6.85 & 0.34 & 5.91 \\
\hline TL SE 01-SE 03230 kV C2 & - & - & - & - & 0.41 & 6.85 & 0.34 & 5.91 \\
\hline TL SE 01-SE NEW ThP $230 \mathrm{kV} \mathrm{C1}$ & - & - & - & - & 2.85 & 21.2 & 3.12 & 12.43 \\
\hline TL SE 01-SE NEW ThP $230 \mathrm{kV}$ C2 & - & - & - & - & 2.85 & 21.2 & 3.12 & 12.43 \\
\hline
\end{tabular}

Table 7. SE-01 circuit breaker current for short circuit applied in SE-05 buses.

(TL: Transmission Line).

\begin{tabular}{|l|c|c|c|c|c|c|c|c|}
\hline \multirow{2}{*}{ Circuit Breaker } & \multicolumn{4}{|c|}{ Base Case } & \multicolumn{4}{c|}{ After ThP link-up } \\
\cline { 2 - 11 } & \multicolumn{2}{|c|}{ 3-phase } & \multicolumn{2}{|c|}{ Single Phase } & \multicolumn{2}{c|}{ 3-phase } & \multicolumn{2}{c|}{ Single Phase } \\
\cline { 2 - 10 } & $\begin{array}{c}\text { Current } \\
(\mathbf{k A})\end{array}$ & $\mathbf{X} / \mathbf{R}$ & $\begin{array}{c}\text { Current } \\
(\mathbf{k A})\end{array}$ & $\mathbf{X} / \mathbf{R}$ & $\begin{array}{c}\text { Current } \\
(\mathbf{k A})\end{array}$ & $\mathbf{X} / \mathbf{R}$ & $\begin{array}{c}\text { Current } \\
(\mathbf{k A})\end{array}$ & $\mathbf{X} / \mathbf{R}$ \\
\hline TL SE 01-SE 05 230 kV & 3.89 & 5.98 & 3.02 & 5.45 & 8.49 & 8.14 & 7.79 & 6.77 \\
\hline
\end{tabular}

Table 8. SE-01 circuit breaker current for short circuit applied in SE-03 buses.

(TL: Transmission Line).

\begin{tabular}{|c|c|c|c|c|c|c|c|c|}
\hline \multirow{2}{*}{ Circuit Breaker } & \multicolumn{4}{|c|}{ Base Case } & \multicolumn{3}{c|}{ After ThP link-up } \\
\cline { 2 - 11 } & \multicolumn{2}{|c|}{ 3-phase } & \multicolumn{2}{|c|}{ Single Phase } & \multicolumn{2}{|c|}{ 3-Phase } & \multicolumn{2}{c|}{ Single Phase } \\
\cline { 2 - 10 } & $\begin{array}{c}\text { Current } \\
(\mathbf{k A})\end{array}$ & $\mathbf{X} / \mathbf{R}$ & $\begin{array}{c}\text { Current } \\
(\mathbf{k A})\end{array}$ & $\mathbf{X} / \mathbf{R}$ & $\begin{array}{c}\text { Current } \\
(\mathbf{k A})\end{array}$ & $\mathbf{X} / \mathbf{R}$ & $\begin{array}{c}\text { Current } \\
(\mathbf{k A})\end{array}$ & $\mathbf{X} / \mathbf{R}$ \\
\hline TL SE 01-SE 03 230 kV C1 & 1.34 & 5.73 & 0.64 & 4.26 & 1.99 & 6.24 & 1.38 & 4.47 \\
\hline TL SE 01-SE 03 230 kV C2 & - & - & - & - & 1.99 & 6.24 & 1.38 & 4.47 \\
\hline
\end{tabular}

Table 9. SE-01 circuit breaker current for shorts circuit applied in SE-02 buses.

(TL: Transmission Line).

\begin{tabular}{|c|c|c|c|c|c|c|c|c|}
\hline \multirow{2}{*}{ Circuit Breaker } & \multicolumn{4}{|c|}{ Base Case } & \multicolumn{4}{c|}{ After ThP link-up } \\
\cline { 2 - 11 } & \multicolumn{2}{|c|}{ 3-phase } & \multicolumn{2}{|c|}{ Single Phase } & \multicolumn{2}{|c|}{ 3-phase } & \multicolumn{2}{c|}{ Single Phase } \\
\cline { 2 - 10 } & $\begin{array}{c}\text { Current } \\
(\mathbf{k A})\end{array}$ & $\mathbf{X} / \mathbf{R}$ & $\begin{array}{c}\text { Current } \\
(\mathbf{k A})\end{array}$ & $\mathbf{X} / \mathbf{R}$ & $\begin{array}{c}\text { Current } \\
(\mathbf{k A})\end{array}$ & $\mathbf{X} / \mathbf{R}$ & $\begin{array}{c}\text { Current } \\
(\mathbf{k A})\end{array}$ & $\mathbf{X} / \mathbf{R}$ \\
\hline TL SE 01 - SE 02 230 kV C1 & 0.39 & 6.77 & 0.54 & 6.94 & 2.37 & 10.39 & 2.12 & 7.3 \\
\hline TL SE 01 - SE 02 230 kV C2 & - & - & - & - & 2.37 & 10.39 & 2.12 & 7.3 \\
\hline
\end{tabular}

Table 10. SE-01 circuit breaker current for short circuit applied in SE new ThP buses.

(TL: Transmission Line).

\begin{tabular}{|c|c|c|c|c|c|c|c|c|}
\hline \multirow{2}{*}{ Circuit Breaker } & \multicolumn{4}{|c|}{ Base Case } & \multicolumn{4}{c|}{ After ThP link-up } \\
\cline { 2 - 11 } & \multicolumn{2}{|c|}{ 3-phase } & \multicolumn{2}{|c|}{ Single Phase } & \multicolumn{2}{c|}{ 3-phase } & \multicolumn{2}{c|}{ Single Phase } \\
\cline { 2 - 10 } & $\begin{array}{c}\text { Current } \\
(\mathbf{k A})\end{array}$ & $\mathbf{X} / \mathbf{R}$ & $\begin{array}{c}\text { Current } \\
(\mathbf{k A})\end{array}$ & $\mathbf{X} / \mathbf{R}$ & $\begin{array}{c}\text { Current } \\
(\mathbf{k A})\end{array}$ & $\mathbf{X} / \mathbf{R}$ & $\begin{array}{c}\text { Current } \\
(\mathbf{k A})\end{array}$ & $\mathbf{X} / \mathbf{R}$ \\
\hline TL SE 01 - SE NEW ThP 230 kV C1 & - & - & - & - & 2.34 & 6.24 & 2.19 & 6.04 \\
\hline TL SE 01 - SE NEW ThP 230 kV C2 & - & - & - & - & 2.34 & 6.24 & 2.19 & 6.04 \\
\hline
\end{tabular}


As indicated in ONS Grid Procedures [15], threephase faults were applied while monitoring circuit breaker first pole openings in buses $(230 \mathrm{kV})$ and terminal faults (grounded and ungrounded). In the application of single-phase short-line faults, the fault was applied at a distance from the terminal line to obtain a current of approximately $90 \%$ of the corresponding terminal fault. The circuit breaker pole that interrupts the fault shall be the last to open, and it is monitored to obtain the greatest initial TRV growth rate (ITRV). First, in all simulations, the fault considered was applied in steady state and second, after initiated in time, poles were opened to analyze TRV transient waveforms. The values used in the comparison for the TRV envelope for short-line and terminal faults adopted for reference purposes are the presumed values cited in IEC Norm 62271-100 [8] and presented in Tables 11 and 12 as follows. For each terminal fault simulation or faults applied to buses, envelopes were considered according to the verified short-circuit current levels.

Regarding short-line faults, Standard IEC 62271100 [8] establishes one basic envelope as shown in Table 12 for all levels of short-circuit currents that in reality are based upon the evolution of the TRV component on the source side that does not take into account the TRV evolution on the side line, which consequently does not permit a precise analysis of the initial moments of the TRV evolution between circuit breaker terminals. Standard [8] defines the calculation methodology for additional values used to verify the growth of the rate of rise for the initial TRV (ITRV) moments associated with the first voltage reflections on the line side, which represents a parameter of major interest due to the characteristics of this type of fault. Based on Standard [8] criteria, for the circuit breaker characteristics and the maximum short circuit current to be interrupted, the ITRV value found for this scenario is $5.35 \mathrm{kV} / \mu \mathrm{s}$.

Initially, TRV analyses were conducted in the existing circuit breaker in the system. Afterwards, with the connection of the new ThP through two $10.7 \mathrm{~km}$ transmission lines, the impacts of the modifications on TRV behavior in existing circuit breakers were then verified. To observe whether the existing interconnection circuit breaker at the SE-01 substation was able to satisfactorily substitute the entry circuit breaker on transmission lines at SE-01 - SE New ThP C1 and C2, these circuit breakers were included in the TRV study by considering the interconnecting circuit breaker characteristics with a rated interruption capacity of $20 \mathrm{kA}$.

ATPDraw [9] software was used to model and simulate system situations. The transmission lines were represented by a model of distributed parameters. The concentrated capacitance of elements connected to circuit breaker terminal buses was considered. The circuit breaker electric arc was not represented. The short-circuit equivalents were calculated according to the database taken from ONS [11] by considering maximum short-circuit levels.

Table 11. TRV Envelopes - Terminal Faults - Norm IEC 62271-100 - First Pole Factor $=1.5$.

\begin{tabular}{|c|c|c|c|c|c|c|c|}
\hline $\begin{array}{c}\text { Rated Breaking } \\
\begin{array}{c}\text { Current \% } \\
(\mathbf{2 0 ~ k A})\end{array}\end{array}$ & $\begin{array}{c}\text { Rated } \\
\text { Voltage } \\
(\mathbf{k V})\end{array}$ & $\begin{array}{c}\text { First Pole } \\
\text { Factor }\end{array}$ & $\begin{array}{c}\text { 1st Voltage } \\
\text { Reference U1 } \\
(\mathbf{k V})\end{array}$ & $\begin{array}{c}\text { Time 1 } \\
(\boldsymbol{\mu s})\end{array}$ & $\begin{array}{c}\text { Growth Rate } \\
\mathbf{U 1 / T 1}(\mathbf{k V} / \boldsymbol{\mu s})\end{array}$ & $\begin{array}{c}\text { TRV Peak } \\
(\mathbf{k V})\end{array}$ & $\begin{array}{c}\text { Time 2 } \\
(\boldsymbol{\mu s})\end{array}$ \\
\hline $10 \%$ & $245 \mathrm{kV}$ & 1.5 & - & - & 7.00 & 459.10 & 65.59 \\
\hline $30 \%$ & $245 \mathrm{kV}$ & 1.5 & - & - & 5.00 & 462.10 & 92.42 \\
\hline $60 \%$ & $245 \mathrm{kV}$ & 1.5 & 225.05 & 75.02 & 3.00 & 450.09 & 450.09 \\
\hline $100 \%$ & $245 \mathrm{kV}$ & 1.5 & 225.05 & 112.52 & 2.00 & 420.09 & 450.09 \\
\hline
\end{tabular}

Table 12. TRV envelopes for Kilometric Faults - Norm IEC 62271-100.

\begin{tabular}{|c|c|c|c|c|c|c|c|}
\hline $\begin{array}{c}\text { Rated Breaking } \\
\text { Current \% } \\
(\mathbf{2 0} \mathbf{~ k A})\end{array}$ & $\begin{array}{c}\text { Rated } \\
\text { Voltage } \\
(\mathbf{k V})\end{array}$ & $\begin{array}{c}\text { First Pole } \\
\text { Factor }\end{array}$ & $\begin{array}{c}\text { 1st Voltage } \\
\text { Reference U1 } \\
(\mathbf{k V})\end{array}$ & $\begin{array}{c}\text { Time 1 } \\
(\boldsymbol{\mu s})\end{array}$ & $\begin{array}{c}\text { Growth Rate } \\
\mathbf{U 1} / \mathbf{T 1} \mathbf{( k V / \mu s})\end{array}$ & $\begin{array}{c}\text { TRV Peak } \\
(\mathbf{k V})\end{array}$ & $\begin{array}{c}\text { Time 2 } \\
(\boldsymbol{\mu s})\end{array}$ \\
\hline $100 \%$ & $245 \mathrm{kV}$ & 1 & 150.03 & 75.02 & 2.00 & 280.06 & 300.00 \\
\hline
\end{tabular}

Note: envelope values shown in the Standard support TRV behavior on the source side 
Simulations were conducted, and the TRV results for the SE-01 configuration in the Base Case with the inclusion of the thermal plant connection are shown in Tables 13 and 14, respectively. Figures 7 and 8 exemplify the TRVs analyzed and their respective envelopes.
As expected, in all cases, the worst TRV maximum amplitude scenarios were observed during the interruption of ungrounded three-phase terminal short circuits. Similarly, the worst initial growth rates were observed for short line fault interruptions. The TRV values obtained remained within the envelope

Table 13. Simulation Results -Circuit breakers at SE-01- Base Case Scenario.

\begin{tabular}{|c|c|c|c|c|c|c|c|}
\hline \multirow{2}{*}{ Circuit Breaker Location } & \multicolumn{2}{|c|}{ Defect } & \multicolumn{3}{|c|}{ Breaker Current } & \multirow{2}{*}{$\begin{array}{l}\text { TRT } \\
(\mathrm{kV})\end{array}$} & \multirow{2}{*}{$\begin{array}{l}\text { TCTRI } \\
(\mathrm{kV} / \mu \mathrm{s})\end{array}$} \\
\hline & Location & Type & kAp & kAef & $\%^{1}$ & & \\
\hline \multirow{5}{*}{ TL SE 01-SE $03230 \mathrm{kV}$} & Terminal & $3 \mathrm{~F}-\mathrm{T}$ & 5.08 & 3.59 & $17.96 \%$ & 318.46 & 0.82 \\
\hline & Terminal & $3 \mathrm{~F}$ & 5.08 & 3.59 & $17.96 \%$ & 404.65 & 0.81 \\
\hline & Bus - $230 \mathrm{kV}$ & $3 \mathrm{~F}-\mathrm{T}$ & 0.97 & 0.69 & $3.43 \%$ & 389.06 & 0.18 \\
\hline & Bus - $230 \mathrm{kV}$ & $3 \mathrm{~F}$ & 0.97 & 0.69 & $3.43 \%$ & 395.21 & 0.17 \\
\hline & Short-line & $1 \mathrm{~F}-\mathrm{T}$ & 3.67 & 2.60 & $12.98 \%$ & 246.1 & 1.11 \\
\hline \multirow{5}{*}{ TL SE 01-SE $02230 \mathrm{kV}$} & Terminal & $3 \mathrm{~F}-\mathrm{T}$ & 0.996 & 0.70 & $3.52 \%$ & 345.79 & 0.14 \\
\hline & Terminal & $3 \mathrm{~F}$ & 0.996 & 0.70 & $3.52 \%$ & 426.29 & 0.19 \\
\hline & Bus $-230 \mathrm{kV}$ & $3 \mathrm{~F}-\mathrm{T}$ & 5.11 & 3.61 & $18.07 \%$ & 331.63 & 0.92 \\
\hline & Bus $-230 \mathrm{kV}$ & $3 \mathrm{~F}$ & 5.11 & 3.61 & $18.07 \%$ & 411.44 & 1.02 \\
\hline & Short-line & $1 \mathrm{~F}-\mathrm{T}$ & 0.63 & 0.45 & $2.23 \%$ & 253.84 & 0.24 \\
\hline \multirow{3}{*}{ TL SE 01-SE $05^{2} 230 \mathrm{kV}$} & Terminal & $3 \mathrm{~F}-\mathrm{T}$ & 6 & 4.24 & $21.21 \%$ & 318.29 & 0.55 \\
\hline & Terminal & $3 \mathrm{~F}$ & 6 & 4.24 & $21.21 \%$ & 408.62 & 0.65 \\
\hline & Short-line & $1 \mathrm{~F}-\mathrm{T}$ & 4.17 & 2.95 & $14.74 \%$ & 254.22 & 1.25 \\
\hline
\end{tabular}

1 Percentage related to circuit breaker rated breaking current (20 kA).

2 TRV circuit breaker short cicuit study not conducted on the TL SE01-SE 05 for bus shorts in $230 \mathrm{kV}$, as there is no current contribution coming from SE 05.

Table 14. Results: SE-01 circuit breaker simulation - thermal plant connection.

\begin{tabular}{|c|c|c|c|c|c|c|c|}
\hline \multirow{2}{*}{ Circuit Breaker Location } & \multicolumn{2}{|c|}{ Defect } & \multicolumn{3}{|c|}{ Circuit Breaker Current } & \multirow{2}{*}{$\begin{array}{l}\text { TRT } \\
(\mathrm{kV})\end{array}$} & \multirow{2}{*}{$\begin{array}{c}\text { ITRV } \\
(\mathrm{kV} / \mu \mathrm{s})\end{array}$} \\
\hline & Location & Type & kAp & kAef & $\% 1$ & & \\
\hline \multirow{5}{*}{ TL SE 01-SE 03230 kV } & Terminal & 3F-T & 13.83 & 9.78 & $48.90 \%$ & 251.57 & 0.77 \\
\hline & Terminal & $3 \mathrm{~F}$ & 13.83 & 9.78 & $48.90 \%$ & 413.63 & 0.8 \\
\hline & Bus - $230 \mathrm{kV}$ & $3 \mathrm{~F}-\mathrm{T}$ & 0.94 & 0.66 & $3.32 \%$ & 379.56 & 0.17 \\
\hline & Bus $-230 \mathrm{kV}$ & $3 \mathrm{~F}$ & 0.94 & 0.66 & $3.32 \%$ & 380.83 & 0.17 \\
\hline & Sort-Line & $1 \mathrm{~F}-\mathrm{T}$ & 12.38 & 8.75 & $43.77 \%$ & 233 & 2.81 \\
\hline \multirow{5}{*}{ TL SE 01-SE 02230 kV } & Terminal & $3 \mathrm{~F}-\mathrm{T}$ & 12.7 & 8.98 & $44.90 \%$ & 268.58 & 0.47 \\
\hline & Terminal & $3 \mathrm{~F}$ & 12.7 & 8.98 & $44.90 \%$ & 360.53 & 0.92 \\
\hline & Bus $-230 \mathrm{kV}$ & $3 \mathrm{~F}-\mathrm{T}$ & 5.06 & 3.58 & $17.89 \%$ & 328.26 & 0.91 \\
\hline & Bus - $230 \mathrm{kV}$ & $3 \mathrm{~F}$ & 5.06 & 3.58 & $17.89 \%$ & 345.03 & 0.94 \\
\hline & Short-Line & $1 \mathrm{~F}-\mathrm{T}$ & 11.39 & 8.05 & $40.27 \%$ & 222.43 & 2.61 \\
\hline \multirow{3}{*}{ TL SE 01-SE $05^{2} 230 \mathrm{kV}$} & Terminal & $3 \mathrm{~F}-\mathrm{T}$ & 13.94 & 9.86 & $49.29 \%$ & 258.51 & 0.62 \\
\hline & Terminal & $3 \mathrm{~F}$ & 13.94 & 9.86 & $49.29 \%$ & 410.03 & 0.5 \\
\hline & Sort-Line & $1 \mathrm{~F}-\mathrm{T}$ & 12.63 & 8.93 & $44.65 \%$ & 246.44 & 2.81 \\
\hline \multirow{5}{*}{ TL SE 01-SE New ThP $230 \mathrm{kV}$} & Terminal & $3 \mathrm{~F}-\mathrm{T}$ & 13.08 & 9.25 & $46.24 \%$ & 272 & 0.5 \\
\hline & Terminal & $3 \mathrm{~F}$ & 13.08 & 9.25 & $46.24 \%$ & 395.85 & 0.63 \\
\hline & Bus $-230 \mathrm{kV}$ & $3 \mathrm{~F}-\mathrm{T}$ & 6.01 & 4.25 & $21.25 \%$ & 421.37 & 1.66 \\
\hline & Bus $-230 \mathrm{kV}$ & $3 \mathrm{~F}$ & 6.01 & 4.25 & $21.25 \%$ & 397.77 & 2.5 \\
\hline & Sort-Line & $1 \mathrm{~F}-\mathrm{T}$ & 11.19 & 7.91 & $39.56 \%$ & 243.94 & 2.43 \\
\hline
\end{tabular}

1 Percentage related to circuit breaker rated breaking current (20 kA).

2 TRV buss $(230 \mathrm{kV})$ short circuit study not conducted forTL SE 01-SE 05circuit breaker as there is no current contribution from SE 05 to be interrupted. 


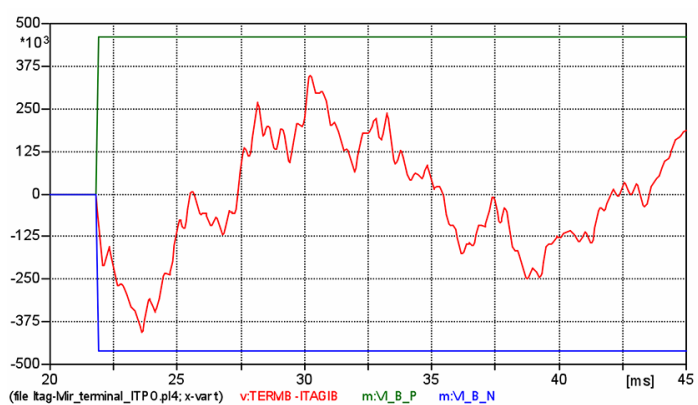

Figure 7. TRV: Circuit breaker in TL SE-01 SE-04 $230 \mathrm{kV}$ due to the interruption of an ungrounded three-phase short circuit applied to the TL terminal.

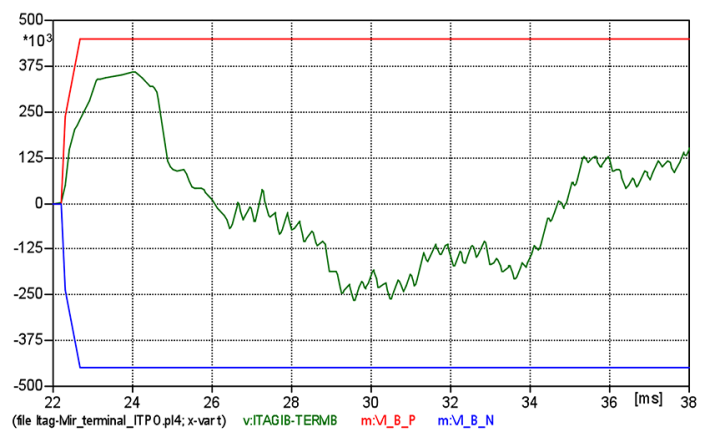

Figure 8.TRV: circuit breakers at TL SE-01 SE-02 $230 \mathrm{kV}$ due to the interruption of an ungrounded three-phase short circuit applied to TL terminal - thermal plant connected to the system.

limits used in the simulations; no circuit breaker violation incidents were observed at SE-01.

\section{INSULATION COORDINATION STUDY}

This study evaluates the occurrence of overvoltages in existing equipment at the $230 \mathrm{kV}$ substation as a result of lightning strokes that hit the transmission lines connected to the new thermal plant.

Based on the physical arrangement of SE-01 substation bays, distances between equipment and discontinuities were calculated and modeled for simulations. The simulations were based on the injection of voltage into transmission lines that connect the new ThP to SE-01, whose times and amplitudes represent overvoltage waveforms that could reach the substation as a result of lightning strokes that hit cable phases (in case of shielding failures) or towers or ground wires capable of promoting a backflashover.

The basic equipment insulation level at SE-01 is $950 \mathrm{kV}$. Based on this value, internal and external insulation safety margins were calculated. These minimal insulation coordination margins, given by the relation between equipment basic insulation levels and overvoltages to which they may be subjected, must be

- For external insulation (air): 5\%;

- For internal insulation (non-regenerative isolations): $15 \%$.

The safety margins above represent maximum overvoltages permitted for internal/external insulation equal to $902.5 \mathrm{kV}$ and $807.5 \mathrm{kV}$, respectively.

System modeling and simulations were conducted using ATPDraw [10] software. The substation was modeled in a single-phase representation. Each connection between any two points was represented by distributed parameters without losses through surge impedance, propagation speed and corresponding lengths. Transmission lines that connect to the substation were represented through distributed parameters, and the equipment connected to buses was represented through their concentrated capacitances (the most important parameter of influence for this type of phenomenon). The simplified $192 \mathrm{kV}$ surge arresters model was determined from applicable insulation coordination studies involving steep impulses [16]. The voltage surge waveform was modeled through a double ramp, as shown in Figure 9. Overvoltages, front times and half-wave times were calculated as functions of the simulated overvoltage.

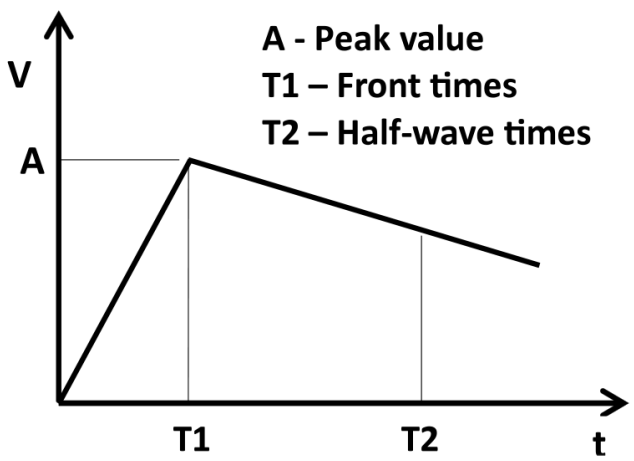

Figure 9. Voltage Waveform. 
Direct lightning strokes are defined as those that connect directly with transmission line phase cables because of shielding failures. Shielding failures are only acknowledged for currents whose values result in admissible overvoltages on transmission lines and do not cause line shutdowns. The maximum current value is denominated Critical Current, whose incidence results in an overvoltage equal to the isolator chain critical supportability V50\%. Currents that have amplitudes above the critical current value shall be intercepted by shielding wires.

The isolator chains at TL SE-01 - New ThP $230 \mathrm{kV}$, consist of 15 isolators representing a critical supportability equal to $1300 \mathrm{kV}$. To simulate overvoltages originating from direct strokes, a voltage surge was considered with an amplitude equal to $1300 \mathrm{kV}$, a front time equal to $1 \mu$ s and a half-wave time equal to $50 \mu \mathrm{s}$.

Indirect strokes are those that reach overhead shield wire or line towers and cause overvoltage capable of producing electric arcs through the isolator chains. This phenomenon is called backflashover. The rupture causes the voltage surge to propagate through the phase cable and if this occurs near a substation, buses and equipment will be affected. Due to its characteristics, the surge creates a steep wave front, considered in the simulation as being equal to $0.5 \mu \mathrm{s}$, with a half-wave time equal to $50 \mu \mathrm{s}$. The maximum surge amplitude $\mathrm{V}_{\mathrm{M}}$ is determined by equation (1), resulting in a value equal to $1417 \mathrm{kV}$ :

$$
V_{M}=V_{50 \%}(1+3 \sigma)
$$

where $\sigma$ is equal to $3 \%$.

In addition to the overvoltage caused by voltage surge injections for an analyzed configuration, the influence of both positive and negative system voltage phase-ground amplitudes $(197.18 \mathrm{kV})$ at the instant a lightning stroke occurs must also be taken into consideration. The resulting value shall remain below the safety margins.

The worst-case substation scenarios, where the maximum overvoltage occurs, were evaluated. Table 15 and Figures 10, 11 and 12 illustrate the configuration study conducted and the results obtained. In this example and other simulations, violations of values superior to the insulation levels and safety margins were not observed in the analyses based on the adopted case premises.

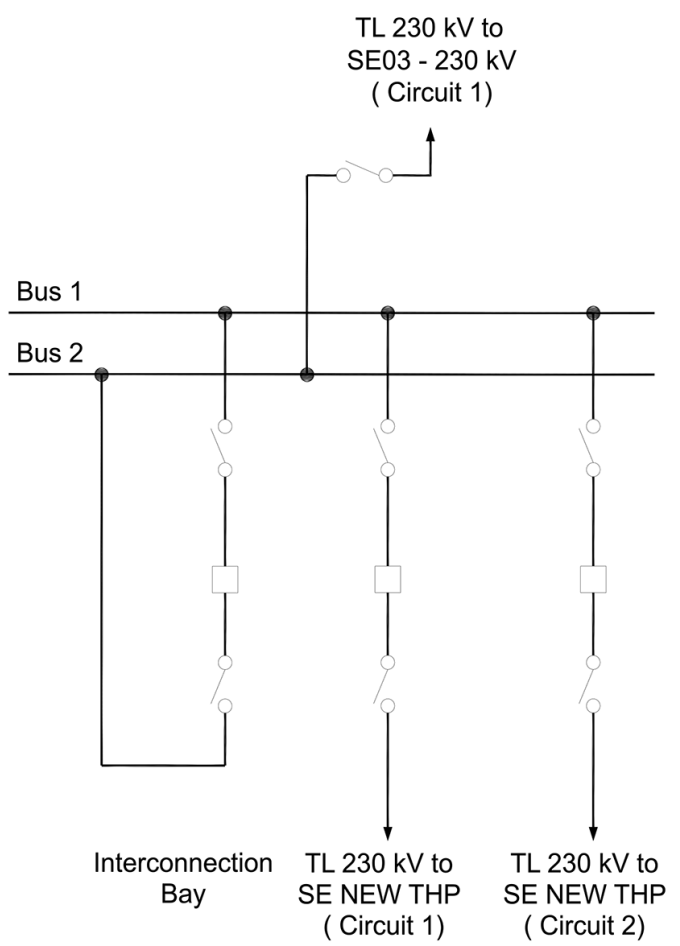

Figure 10. Substation SE-01 - configuration at the TL new thermal plant $\mathrm{C} 1$ and $\mathrm{C} 2$ connected to Bus B1 and TL SE-03 C1 connected to Bus B2 through a ByPass. Interconnection circuit breaker is closed.

Table 15. Main Overvoltages identified.

\begin{tabular}{|c|c|c|c|c|c|c|c|}
\hline \multirow{2}{*}{ Discharge type } & \multirow{2}{*}{ Location of Discharge } & \multirow{2}{*}{$\begin{array}{l}\text { Voltage } \\
(60 \mathrm{~Hz})\end{array}$} & \multirow{2}{*}{$\begin{array}{c}\text { Bay TL SE } \\
\text { 01-SE 03 C1 }\end{array}$} & \multicolumn{2}{|c|}{ Bus } & \multirow{2}{*}{ Reactor } & \multirow{2}{*}{$\begin{array}{c}\text { Tie circuit } \\
\text { breaker }\end{array}$} \\
\hline & & & & B1 & B2 & & \\
\hline \multirow{2}{*}{ Direct } & \multirow{2}{*}{ TL SE 01-SE NEW ThP C1 } & $-1 \mathrm{pu}$ & 469.49 & 471.67 & 480.44 & 420.74 & 447.38 \\
\hline & & $+1 \mathrm{pu}$ & 446.67 & 469.22 & 404.54 & 399.84 & 407.58 \\
\hline \multirow{2}{*}{ Indirect } & \multirow{2}{*}{ TL SE 01-SE NEW ThP C2 } & $-1 \mathrm{pu}$ & 477.32 & 513.91 & 500.78 & 428.69 & 455.22 \\
\hline & & $+1 \mathrm{pu}$ & 503.34 & 530 & 412.44 & 401.07 & 428.06 \\
\hline
\end{tabular}




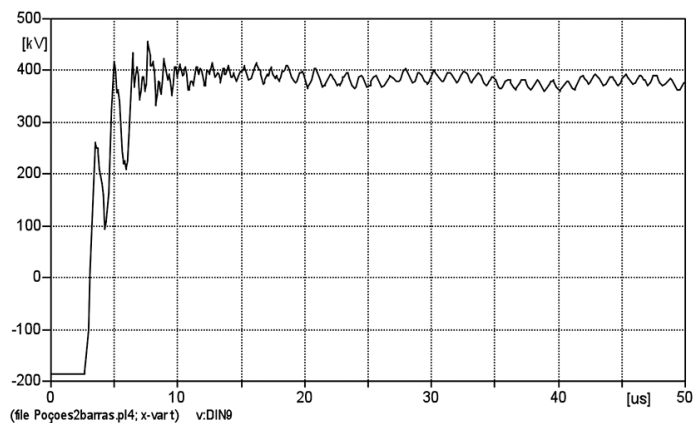

Figure 11. Overvoltage in the Interconnection Bay for Indirect Discharge in line at SE-01New ThP C2.

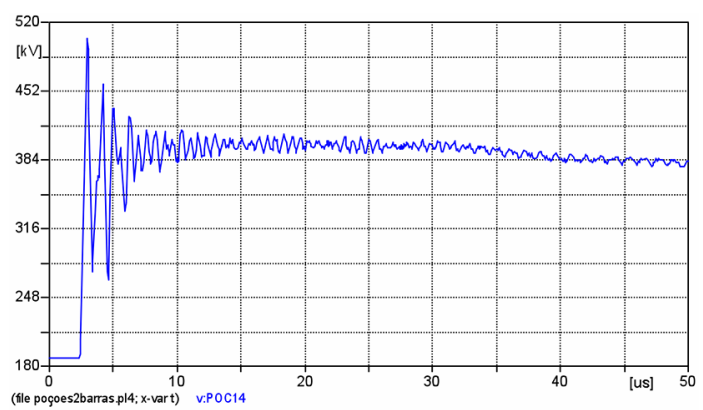

Figure 12. Overvoltage in Bay - TL. SE-01 - SE-03 $\mathrm{C} 1$ for Indirect Discharge in TL SE-01 - New ThP C2.

\section{CONCLUSIONS}

Four studies of major relevance were presented and evaluated to detect problems related to rated characteristic violations in substation equipment and buses in view of a new thermal plant link-up to the basic electric grid through a determined substation. In some cases, evidence of rated bus bar and equipment characteristic violations were observed, resulting from new plant link-ups with the analyzed substation.

In the power flow studies, in Case 2 where some operational contingencies were evaluated, the maximum rated current limit was exceeded for interconnection bay equipment. This overload can be avoided by imposing an operational restriction in which the energy generated by the new thermal plant must be injected into Bus B2, with all other transmission lines connected to Bus B1.

Regarding the $\mathrm{C} 1$ circuit entry bay belonging to TL SE-01 - SE-02, the rated current capacity was exceeded in buses during its emergency operation due to contingency of the $\mathrm{C} 2$ circuit belonging to the same line.

In the study of short-circuit current evaluations, the new thermal plant connection did not cause any limit violations affecting equipment supportability; circuit breakers were able to interrupt new currents imposed on the system according to the premises established in the study.

Equally, in the TRV study, no observations were noted in relation to the violation of electrical limits in SE-01 circuit breakers. The values obtained are well within the envelope limits utilized in simulations.

In the simulations conducted in insulation coordination studies, voltage values superior to equipment insulation limits were not observed for the configurations analyzed within the premises adopted.

The studies presented in this paper were developed in the hope that they will facilitate future analyses of new electric system connections. This article only analyzed stress on substation buses and equipment at a substation with a double bus and single breaker scheme. However, the methodology may be used for substations with other types of bus schemes, mainly in the case of ring and $1 \frac{1}{2}$ circuit breaker configurations where in contingency situations, the current in the equipment and buses can exceed the currents in the substation circuits.

\section{REFERENCES}

[1] A. D'ajuz, F.M. Resende, F.M.S. Carvalho, I.G. Nunes, J.A. Filho, L.E.N. Dias, M.P. Pereira, O. Kastrup e S.A. Morais. "Equipamentos Elétricos: Especificação e Aplicação em Subestações de Corrente Alternada”. Eduff. pp. 276-285. Rio de Janeiro, Brasil. 1985.

[2] Ministério de Minas e Energia, Empresa de Pesquisa Energética. "Plano Decenal de Expansão de Energia 2020”. Brasília, Brasil. 2011. URL: www.epe.gov.br

[3] B. Stott. "Review of load-flow calculation methods". Proceedings of the IEEE. Vol. 62 $\mathrm{N}^{\circ}$ 7, pp. 916-929. 1974.

[4] J.J. Grainger and W.D. Stevenson. "Power system analysis". McGraw-Hill. New York, USA. 1994. 
[5] L. Van Der SLuis. "Transients in power systems". Wiley. 2001.

[6] IEEE Std. C37.011-2005. "Application Guide for Transient Recovery Voltage for AC High - Voltage Circuit Breaker". 2006.

[7] R. Alexander and D. Dufournet. "Transient Recovery Voltage (TRV) For High-Voltage Circuit Breakers". Tutorial IEEE Switchgear Committee. St. Pete Beach. May, 2003.

[8] IEC Std. 62271-100. "High-voltage switchgear and controlgear - Part 100: Alternating-current circuit-breakers". Apr, 2008.

[9] C.L. Wagner and H.M. Smith. "Analysis of transient recovery voltage (TRV) rating concepts". IEEE Trans. on Power Apparatus and Systems. No 11, pp. 3353-3363. 1984.

[10] L. Prikler and H.K. Høidalen. "ATPDraw version 3.5 for Windows 9x. NT/2000/XP Users' Manual". 2002.

[11] ONS - Operador Nacional do Sistema Elétrico. "Plano de Ampliações e Reforços 2012/2014". Dezembro, 2011. URL: www. ons.org.br/plano_ampliacao.
[12] CEPEL - Centro de Pesquisas em Engenharia Elétrica. "ANAFAS - Programa de Análise de Faltas Simultâneas, Tutorial”. Versão 4.3. Abril 2006. URL: www.anafas.cepel.br

[13] CEPEL - Centro de Pesquisas em Engenharia Elétrica. "ANAFAS - Programa de Análise de Faltas Simultâneas, Manual do Usuário". Versão 4.3. Abril, 2006. URL: www.anafas. cepel.br.

[14] ONS-Operador Nacional do Sistema Elétrico. "Procedimentos de Rede, Submódulo 11.3: Estudos de curto-circuito". Revisão 1.0. 2011. URL: www.ons.org.br/procedimentos/index. aspx.

[15] ONS-Operador Nacional do Sistema Elétrico. "Procedimentos de Rede, Submódulo 23.3: Diretrizes e critérios para estudos elétricos". 2011. URL: www.ons.org.br/procedimentos/ index.aspx.

[16] P. Pinceti and M.A. Giannettoni. "Simplified model for zinc oxide surge arresters". IEEE Trans. on Power Delivery. Vol. $14 \mathrm{~N}^{\circ} 2$, pp. 393-398. 1999. 